Mr. sc. Sait Š. ŠABOTIĆ

Filozofski fakultet Nikšić

E-mail:sabos@t-com.me

Stručni rad/Professional article

UDK/UDC: 94:902:39:82:581.9(497.16) (051)

\title{
STARO RUHO - NOVI SADRŽAJI \\ GLASNIK BIHORA, br. 5, JU Centar za kulturu Petnjica, Petnjica 2020, 380 str.
}

Iako će vrijeme od marta 2020. godine u Crnoj Gori ostati upamćeno po otežanim uslovima rada koji su uslijedili sa pandemijom virusa COVID-19, u

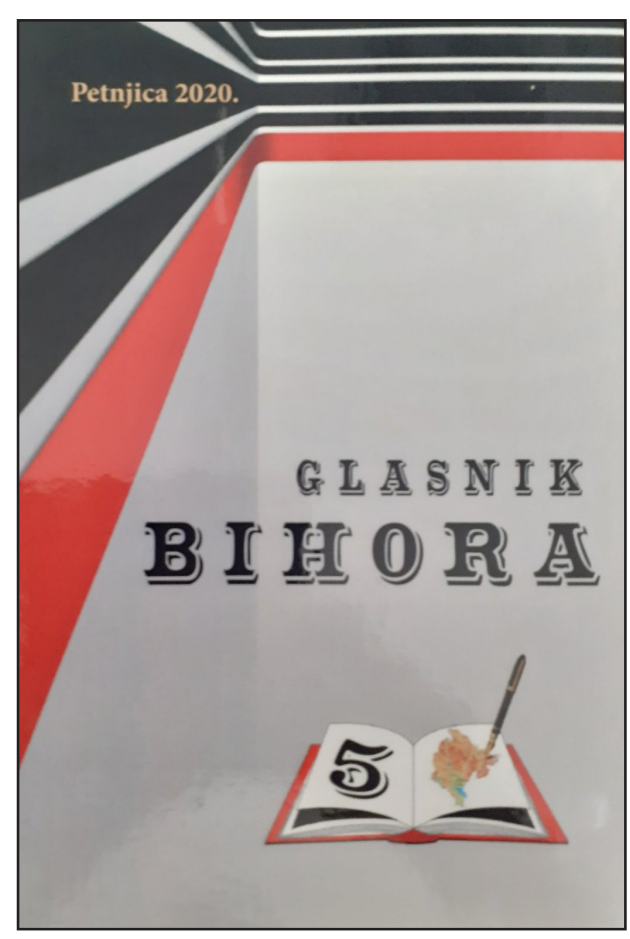
opštini Petnjica nisu poklekli pred ovom preprekom. Potvrđuje to i JU Centar za kulturu koji uspješno nastavlja sa svojom izdavačkom djelatnošću. Vidljiv rezultat na tom polju je peti broj naučnostručnog časopisa Glasnik Bihora, čije je štampanje završeno prije nekoliko dana. Napori članova Redakcionog odbora tokom prikupljanja pisanih priloga za ovaj broj bili su usmjereni ka jednom važnom cilju - da časopis ostane na fonu kvaliteta koji će potvrditi da je njegovo izlaženje sasvim opravdano, dok su autori, ulaganjem dodatnih napora, uspjeli da na vrijeme dostave svoje radove za novi broj časopisa. U takvom timskom radu nastao je ovaj dragocjeni broj glasila na 380 strana, što JU Centar za kulturu i sve njegove saradnike, čini posebno ponosnim.

Peti broj Glasnika Bihora zadržao je staro ruho - naslovnu stranu i strukturu koju čini nekoliko prepoznatljivih rubrika: Baština, Istorija, Dokumenti, Arheologija, Književnost, Botanika, Prikazi.

Već u prvoj rubrici sa nazivom Baština, daje se nekoliko novih priloga, čiji autori otvaraju važna pitanja kao što su etika sabura, zatim hodonimija Bijelog Polja, kao i pitanje imama Gornjeg Bihora. Autori ovih radova su Esko Muratović, Draško Došljak i Bajro Agović. U razmatranju etike sabura Esko Muratović svoje hermeneutičke sonde usmjerava ka tumačenju i razumijevanju ljudske opstojnosti $i$ 
moralnog pregalaštva, sa ciljem da se na pojmovan i racionalan način, kroz misaonu obrazloživost, logičku koherentnost $i$ hermeneutičnu provjerljivost, zađe u jedno neistraženo polje stanja $i$ veličine duha bošnjačkog čovjeka. Etiku sabura autor vidi kao koegzistencijsku kodificiranost opstajanja bošnjačkog naroda, kao stalnu strpljivost, ali za nju veže i neke druge pojmove kao što su selamet, samozatajnost i samoprevazilaženje.

Saradnik Glasnika Bihora, koji od prvog broja pruža svoju nesebičnu pomoć ovom glasilu, dr. Draško Došljak, u svom radu se bavi hodonimijom po naseljima Bijelog Polja (nazivi ulica, mostova, trgova), i u tom kontekstu donosi obilje korisnog materijala. Prema njegovom istraživanju u Bijelom Polju je zabilježeno 167 hodonima, koji daju preciznu sliku kulturološkog ambijenta u ovom gradu. Hodonimi inače, kao nosioci određenih simbola, predstavljaju različite društvene, političke i kulturne slike, kao i prostorne orjentire. Eksponiranjem hodonima Bijelog Polja, Draško Došljak je čitaoce uveo u specifičan ambijent, koji je tu pred nama, ali koji često ostaje na marginama naših razmišljanja.

Vrijedni kulturni poslenik Bajro Agović, ne posustaje u svojim istraživanjima, pa u ovom broju Glasnika Bihora u svom prilogu daje pregled imama džamije u Petnjici, započinjući hronologiju od Saliha Havadže Hodžića dovodeći je do sadašnjeg imama Huseina efendije Ramčilovića. Napomenimo samo da institucija imama u Bihoru ima dugu tradiciju. Ona traje već punih 565 godina i stoga joj, svakako, treba pridavati značaj, voditi računa o biografijama svih imama i onome šta su tokom svog imameta radili.

U okviru rubrike Baština, situirana su još dva priloga. Svojim putopisnim osvrtom na boravak u Sandžaku, Hazeta Salihović iznosi svoje impresije i o Bihoru, njegovim ljudima i mjestima, te o promociji njenih knjiga u Petnjici. Ova topla priča pominje i jedan od prethodnih brojeva Glasnika Bihora, koji ova književnica toplo preporučuje za čitanje.

Sjećanje na Muja Rastodera, boema, čovjeka odanog zavičaju, poklonika pisane riječi, i zaljubljenika u dvotočkaše, daje Reho Ramčilović kao njegov dugogodišnji kolega i prijatelj. U riječima posvećenim Muji, koje su satkane od niti ljubavi i prožete sjetom, lako je uočiti šta je on značio Petnjici i šta je Petnjica značila njemu.

Rubrika Istorija, koja budi posebnu pažnju čitalaca, i ovoga puta nudi nove sadržaje. Ona sadrži tri rada tematski različita, ali neraskidivo povezana sa stanovnicima bihorskog kraja. Izet Šabotić, redovni profesor na studijskom programu za istoriju Filozofskog fakulteta Univerziteta u Tuzli, piše o jednom slučaju krvne osvete među Gornjobihorcima i to na osnovu arhivske građe Državnog Arhiva na Cetinju. Fenomen krvne osvete, kao dio običajnih normi, dugo je bio prisutan na prostoru Bihora. U surovim uslovima života, Bihorci su imali i vrlo izgrađeni kodeks ponosa i časti. Za nanijetu uvredu, počinjeno ubistvo ili slične situacije, najčešće je slijedila osveta. Događaj koji nam rasvjetljava Izet Šabotić, dogodio se početkom XX vijeka, a njegove posljedice trajale su i niz decenija nakon direktnog sukoba 
bratstvenika Rastodera i Škrijelja. Uz detalje ovog sukoba, Izet Šabotić nas upoznaje i sa detaljima djelovanja muslihunskih vijeća, koja su imala vidnu i nezaobilaznu ulogu u slučajevima mirenja zavađenih pojedinaca i bratstava.

Drugi rad u okviru temata posvećenog istoriji, jeste rad istoričara Esada Rahića iz Novog Pazara. U svom tekstu Rahić se bavi refleksijama Berlinskog kongresa na stanje u Novopazarskom sandžaku, čiji je sastavni dio bila i kaza Akova sa Bihorom. Tokom događaja vezanih za Istočnu krizu koji su doveli do okupacije najvećeg dijela Bosanskog vilajeta, odnosno njegovih šest sandžaka, od strane Austro-Ugarske, sedmi i najistočniji dio tog prostora - Novopazarski sandžak, bio je odvojen od Bosne i Hercegovine i pripojen novoosnovanom Kosovskom vilajetu. U sastavu te administrativne cjeline Osmanske države, Bihor će ostati sve do 1912. godine, preživljavajući dramatične istorijske trenutke.

Dešavanja u poslednjoj jugoslovenskoj ratnoj drami, kako neki nazivaju događaje povezane sa disolucijom SFR Jugoslavije, ostavili su za sobom trajne posljedice. Jedan od njih je i genocid nad bošnjačkim stanovništvom, koji se dogodio u Srebrenici 1995. godine. Od njega je proteklo 25 bolnih godina i upravo toj godišnjici svoju pažnju je posvetio dr. Azem Kožar, dugogodišnji profesor Univerziteta u Tuzli. Razmatrajući mnoge aspekte vezane za pomenuti događaj, Kožar ukazuje na činjenicu da shodno odredbama Konvencije o genocidu u pravnim kvalifikacijama organizovanog i ciljanog uništavanja kulturnih dobara u presudama Međunarodnog krivičnog suda za bivšu Jugoslaviju (MKSJ) u Hagu ova vrsta zločina nije uvrštena u okvire pojma najtežeg ratnog zločina - zločina genocida. U svojim daljim elaboracijama autor ukazuje na osobenosti i razmjere ratnog stradanja kulturnih dobara Bosne i Hercegovine, na pravnosudsko razumijevanje ove vrste ratnog zločina kao planiranog i svjesnog uništavanja kulturnih dobara jedne etničke grupe u cilju uništenja njenog kulturnog identiteta, te u skladu s tim i spoznajom da se prije 70 godina donesena Konvencija o genocidu neminovno treba i mora mijenjati i dopunjavati, pored ostalog i uključivanjem kulturocida u okvire zločina genocida.

Cijeneći značaj istorijskih izvora kao osnove za bilo koju vrstu izučavanja, akademik prof. dr Šerbo Rastoder je za rubriku Dokumenti ustupio dva priloga, koji su nedavno objavljeni u časopisu Almanah. Važno je napomenuti da je informativna vrijednost ovih dokumenata veoma bitna i da će, svakako, prvi prilog biti od koristi onima koji se budu bavili rodoslovljem, dok će drugi, koji se vezuje za pogibiju poznatih revolucionara iz bjelopoljskog i pljevaljskog kraja - Rifata Burdžovića Trša, Vladimira Kneževića Volođe i Tomaša Žižića, biti korisno upotrijebljen u više različitih konteksta.

Rubrika Arheologija zastupljena je sa jednim prilogom koji dolazi iz pera mladog arheologa Burhana Čelebića. On je studije arheologije završio na Istanbul Univerzitetu u Istanbulu, nakon čega se vratio u rodno Bijelo Polje. Ovaj prilog je dragocjen, jer ukazuje na pojedine dimenzije arheoloških istraživanja, koje su, do nedavno, kada je u pitanju područje Bihora, bili gotovo nepoznati. Pored toga, ovim svojim radom arheolog Čelebić jasno ukazuje na činjenicu da bi arheološka 
istraživanja u Bihoru morala imati svoj kontinuitet, ukoliko žele biti vidljivi konkretni rezultati proučavanja starijih perioda ljudske prošlosti.

Tema Književnost i u ovom broju obiluje prilozima koji dolaze iz pera više autora. Među njima su Ulvija Mušović, Čedo Baćović, Dijana Tiganj, Ferid Muratović, Radosav Minja Koprivica i Reho Ramčilović. Kroz tekstove ovih autora afirmiše se Bihor, njegovi stvaraoci, slika specifičan mentalitet ljudi sa ovog podneblja i ukazuje na prošlost kraja pričom koja se prenosi kroz vrijeme.

Rubrika Botanika donosi jedan prilog čiji je autor Ilhan Škrijelj. Ovaj mladi stvaralac se svojski potrudio da na sistematičan način predstavi floristička i vegetacijska istraživanja opštine Petnjica i izdvoji sve biljne vrste koje se javljaju u pomenutom arealu.

Rubrika Prikazi sadrži osvrte na najznačajnija ostvarenja iz različitih područja, sa intencijom da su autori ljudi koji potiču iz Bihora, da je samo djelo nastalo u Bihoru ili da govori o Bihoru. U ovom broju Glasnika Bihora predstavljeno je devet vrijednih izdanja među kojima su i ona čiji su autori ili urednici Faiz Softić, Rifat Rastoder, Šerbo Rastoder, Mišo Drašković, Latif Adrović, Zehnija Bulić, kao i autori koji su pisali tekstove za monografiju bratstva Kožar ili oni koji su se osvrnuli na život i djelo Branke Bogavac. Autori prikaza u ovom broju Glasnika su: Draško Došljak, Braho Adrović, Dejana Brajaktarović Joksimović, Sait Š. Šabotić, Fehim Ličina, Željko Drinčić, Bajro Agović i Safet Hadrović Vrbički.

Na kraju, upućujemo iskrenu zahvalnost svim autorima radova, saradnicima, kolegama i prijateljima, koji su na bilo koji način pomogli štampanje petog broja Glasnika Bihora. Očekujemo da će i naši čitaoci znati da prepoznaju uloženi napor u stvaranju ovog broja, koji, na izvjestan način, predstavlja i prvi jubilarni broj u misiji koja je tek, nadamo se, započela. 